\title{
The effect of administering vaginal estrogen to clomiphene citrate stimulated cycles on endometrial thickness and pregnancy rates in unexplained infertility Açıklanamayan infertilite tedavisinde klomifen sitrat ile uyarlan sikluslara vajinal östrojen eklenmesinin endometrial kalınlı ve gebelik oranlarına etkisi
}

\author{
Kadir Çetinkaya ${ }^{1}$, Sedat Kadanalı ${ }^{2}$ \\ 'Department of Gynecology and Obstetrics, Ankara Oncology Education and Research Hospital, Ankara, Turkey \\ ${ }^{2}$ Department of Gynecology and Obstetrics, Istanbul Medicalpark Hospital, Istanbul, Turkey
}

\section{Abstract} Objective: Clomiphene citrate (CC) has some negative effects on the
endometrium. We aimed to determine the effect of vaginally adminis-
tered local estrogen (LE) on endometrial thickness (ET) and pregnancy
rates in CC stimulated cycles.

Material and Methods: This was a prospective randomized crossover study that took place in a university hospital. The patients had received CC due to unexplained infertility (UI). Two different treatment protocols were given sequentially as, either $\mathrm{CC}+\mathrm{LE}$ or $\mathrm{CC}$ alone. Each protocol was planned for two cycles and there was a one-month wash-out period between protocols. The effects of LE on the $3^{\text {rd }}$ and $9^{\text {th }}$ day, the ovulation day (OD) and $7^{\text {th }}$ postovulation day (POD7) were investigated Results: A total of 6 pregnancies were achieved with 3 patients from each protocol. The ET was $7.6 \pm 1.4 \mathrm{~mm}$ and $8.3 \pm 2.1 \mathrm{~mm}$ respectively and significantly different in the $\mathrm{CC}$ group and the $\mathrm{CC}+\mathrm{E} 2$ groups on the OD $(p=.039)$, while these values were $9.7 \pm 2.3 \mathrm{~mm}$ and $10.9 \pm 3.0$ $\mathrm{mm}$ respectively and significantly different on the POD7 $(p=.007)$. There was no significant difference between the groups for arterial PI values on the OD and POD7. The frequency of thin endometrium $(<6 \mathrm{~mm})$ was $15.2 \%$ and $12.2 \%$ respectively in the CC group and the $\mathrm{CC}+\mathrm{E} 2$ group on the OD $(\mathrm{p}=.628)$ and $5.1 \%$ and $1.2 \%$ respectively on the POD7 ( $\mathrm{p}=.182)$.

Conclusion: Adding vaginal LE to CC stimulated cycles led to a significant increase in ET on the OD and POD7. However, this difference in thickness was not reflected in the pregnancy rates in this study.

(J Turkish-German Gynecol Assoc 2012; 13: 157-61)

Key words: Infertility, clomiphene citrate, estrogen, endometrial thickness, pregnancy

Received: 11 February, 2012

Accepted: 12 May, 2012

\section{Introduction}

Clomiphene citrate (CC) accelerates the development of an ovum suitable for fertilization with its systemic effect on the hypothalamus-ovary axis, but can also have no effect or a detrimental effect on the endometrium the fertilized ovum will attach to $(1,2)$. The endometrial proliferation can sometimes even be less than the ideal thickness (3). It therefore prevents

\section{Özet}

Amaç: Klomifen sitrat (CC)'ın endometrium üzerinde bazı olumsuz etkileri vardır. CC ile uyarılmış sikluslara vajinal yoldan uygulanan lokal östrojen (LE)'nin endometrial kalınlık (ET) ve gebelik oranları üzerine etkisini belirlemeyi amaçladık.

Gereç ve Yöntemler: Üniversite hastanesinde gerçekleştirilen prospektif randomize çapraz karşılaştırmalı bir çalışmadır. Hastalar açıklanamayan infertilite (UI) nedeniyle CC aldılar. İki farklı tedavi protokolü ardışık olarak ya CC+LE ya da tek başına CC verildi. Her protokol iki siklus olarak planlandı ve protokoller arasında bir ay kadar yıkama için bekleme süresi bırakıldı. LE'nin etkileri 3. gün, 9. gün, yumurtlama günü (OD) ve yumurtlama sonrası 7. gün (POD7) incelendi.

Bulgular: Her protokolde 3'er olmak üzere toplam 6 gebelik elde edildi. CC grubu ve CC+E2 grubunda ET sirasiyla $7.6 \pm 1.4 \mathrm{~mm}$ ve $8.3 \pm 2.1 \mathrm{~mm}$ OD anlamlı farklı $(\mathrm{p}=.039)$ iken, bu değerler POD7 sırasıly $9.7 \pm 2.3 \mathrm{~mm}$ ve $10.9 \pm 3.0 \mathrm{~mm}$ yine anlamlı farklı idi $(\mathrm{p}=.007)$. OD ve POD7 arteriyel PI değerleri için gruplar arasında anlamlı fark yoktu. İnce endometrium ( $<6 \mathrm{~mm}$ ) sıklığı $\mathrm{CC}$ grubu ve $\mathrm{CC}+\mathrm{E} 2$ gruplarında sirasıyla OD \%15.2 ve \%12.2 $(\mathrm{p}=.628)$ ve POD7 $\% 5.1$ ve $\% 1.2$ $(\mathrm{p}=.182)$ idi.

Sonuç: CC ile uyarılan sikluslara vajinal yolla LE eklenmesi OD ve POD7'de ET için anlamlı artış sağlamıştır. Ancak ET artışı bu çalışmada gebelik oranlarına yansımamıştır.

(J Turkish-German Gynecol Assoc 2012; 13: 157-61)

Anahtar kelimeler: İnfertilite, klomifen sitrat, östrojen, endometrium kalınlı̆̆ı, gebelik

Geliş Tarihi: 11 Şubat 2012

Kabul Tarihi: 12 Mayıs 2012 
endometrium and cervical mucus level $(2,5)$. The endometrial effect is without doubt one of the most important handicaps in infertility treatment. The pregnancy rate can be very low, especially if the endometrial thickness (ET) is $<6-8 \mathrm{~mm}(1,3,6)$. The systemic administration of estrogen has been used to overcome the ET lowering effect of CC. A major limitation of oral estrogen therapy is undoubtedly the first-pass effect in the gastrointestinal system that leads to metabolism of a major portion of estrogen before reaching the target tissue. Additionally, higher serum estrogen levels can interfere with the anti-estrogenic effect of $\mathrm{CC}$ that leads to superovulation. We hypothesized that vaginal administration of estrogen can protect the estrogen from liver metabolism before reaching the endometrium, thus obtaining a favorable ET for achieving better pregnancy rates. As far as we are aware, it is yet unknown whether vaginally added local estrogen (LE) can be effective in decreasing the unfavorable effect of $\mathrm{CC}$ on endometrium and occurrence of pregnancy. The aim of this study was to evaluate the effect of vaginally administered estrogen on the ET and uterine blood flow and therefore on pregnancy rates in women who had undergone ovulation induction (OI) with CC.

\section{Material and Methods}

\section{Patients}

Before entering the study, all patients received a complete infertility workup and were diagnosed as having unexplained infertility (UI) for at least one year. Unexplained infertility was defined as normal findings in the infertility evaluation. A total of 67 UI patients were admitted to Atatürk University Medical Faculty Department of Obstetrics and Gynecology between July 1, 2008 and July 1, 2009 and were scheduled to receive OI with CC. The patients were provided oral and/or written information and Ethic Committee permission was also obtained. Patients aged 18 to 35 who had received a diagnosis of UI with a $3^{\text {rd }}$ day FSH value $<10 \mathrm{mIU} / \mathrm{ml}$ and estrogen (E2) value $>40 \mathrm{pg} / \mathrm{ml}$, with bilateral tubal patency found on hysterosalpingography or laparoscopy, were included in the study. Those with a major medical problem, patients who had past ovarian or adnexial surgery, where a male factor that could cause infertility was present, patients with an endocrine disease such as hyperprolactinemia or abnormalities of their thyroid function test results, those who had used a hormonal drug in the last 6 months, patients with a body mass index $>30 \mathrm{~kg} / \mathrm{m}^{2}$ and those with an organic pelvic disease were excluded from the study.

\section{Treatment protocols}

We had two treatment protocols as the $\mathrm{CC}+\mathrm{E} 2$ group and the $\mathrm{CC}$ alone group. Ovulation induction was administered to both groups for 5 days with CC $50 \mathrm{mg}$ b.i.d oral tablets (Klomen ${ }^{\circledR}$ tablet, Koçak Farma, Turkey) on the $4^{\text {th }}$ to $8^{\text {th }}$ days of the cycle for a total of $100 \mathrm{mg}$ daily in patients where no pathology was found on the $3^{\text {rd }}$ day (D3) basal vaginal ultrasonograpy (USG). Estrogen (E2) administration was with 25 microgram vaginal tablets (Vagifem ${ }^{\circledR}$ tablet, Novo Nordisk, Denmark) for 15 days starting on the $4^{\text {th }}$ day of the cycle in the CC+E2 group. Ovulation was triggered by 10000 IU hCG when the mean diam- eter of a leading follicle was $\geq 18 \mathrm{~mm}$. Follicle sizes were the average of two dimensions at transvaginal USG. Ovulation day was determined by ultrasonographical examination.

The study was planned to have a crossover design and closed envelope randomization was performed. The assignment was not known to the treating physician or the patient until consent was obtained. The waiting duration (wash-out period) for changing from one treatment method to the other was about one month. Each protocol was planned for two cycles and there was a one-month wash-out period between protocols. USG was performed following spontaneous bleeding on the D3, $9^{\text {th }}$ day (D9), the ovulation day (OD) and the $7^{\text {th }}$ post-ovulation day (POD7) in all patients. Ovulation was confirmed by a serum level of progesterone exceeding $5 \mathrm{ng} / \mathrm{ml}$ on POD7. The ET, subendometrial blood flow (SEBF), uterine artery blood flow (UABF) and follicular development were measured in both ovaries. The systemic E2, FSH, LH and progesterone levels were also studied on the same days. The presence of pregnancy was tested with the beta-hCG level (>100 mIU/ml) and then evaluated with USG during follow-up.

\section{Statistical analyses}

The SPSS 15.0 software was used for statistical analysis. Parametric data were expressed as mean and standard deviation. Differences between groups were compared by Student's $t$ test for independent samples for continuous values and $x^{2}$ test or Fisher's exact test for categorical variables. Variance analysis was used to compare means between the groups. Results with a p value less than 0.05 were considered to be statistically significant.

\section{Results}

A total of 64 of the 67 UI patients who were scheduled to undergo OI with $\mathrm{CC}$ and were invited to the study agreed to participate. Patients who did not come regularly for follow-up $(n=5)$, developed ovarian cysts during follow-up $(n=2)$, or developed additional medical problems $(n=1)$ were excluded for a total of 8 exclusions. The study has two protocols and each protocol was planned for two cycles in crossover design, but it was not possible for each patient to administer two cycles as planned. Ultrasonographical measurements could be obtained at 161 cycles where ovulation was achieved and were analyzed. CC had been used in 79 cycles (49.07\%) and CC + E2 in 82 cycles (50.93\%). The mean patient age was $26.8 \pm 6.2$ and the mean infertility duration 34.2 months.

The ET values in the $\mathrm{CC}$ group and $\mathrm{CC}+\mathrm{E} 2$ group of the patients was $7.6 \pm 1.4 \mathrm{~mm}$ and $8.3 \pm 2.1 \mathrm{~mm}$ on OD $(\mathrm{p}=0.039)$ and $9.7 \pm 2.3 \mathrm{~mm}$ and $10.9 \pm 3.0 \mathrm{~mm}$ on POD7 $(\mathrm{p}=0.007)$, respectively (Table 1 ). We found that ET increased in a significant manner on the OD and POD7 day with LE. However, this increase did not lead to a change in pregnancy rates. Evaluating the patients' pregnancy status showed 3 pregnancies in 79 cycles in the $\mathrm{CC}$ group and 3 pregnancies in 82 cycles in the $\mathrm{CC}+\mathrm{E} 2$ group for a total of 6 pregnancies out of a total of $56(10.7 \%)$. There was no significant difference between groups regarding pregnancy rates. 
Table 1. Endometrial thickness (mm)

\begin{tabular}{|l|c|c|c|}
\hline & CC group & CC + E2 group & p \\
\hline $3^{\text {rd }}$ day & $3.9 \pm 1.0$ & $3.7 \pm 1.1$ & 0.472 \\
\hline $9^{\text {th }}$ day & $6.3 \pm 1.2$ & $6.1 \pm 1.2$ & 0.285 \\
\hline Ovulation day & $7.6 \pm 1.4$ & $8.3 \pm 2.1$ & 0.039 \\
\hline $7^{\text {th }}$ post-ovulation day & $9.7 \pm 2.3$ & $10.9 \pm 3.0$ & 0.007 \\
\hline
\end{tabular}

Table 2. Endometrial thickness $(\mathrm{mm})$ on ovulation day and $7^{\text {th }}$ post-ovulation day

\begin{tabular}{|c|c|c|c|c|c|c|c|}
\hline \multirow[t]{2}{*}{ Treatment Type } & & \multicolumn{3}{|c|}{ Ovulation day } & \multicolumn{3}{|c|}{$7^{\text {th }}$ post-ovulation day } \\
\hline & & $<6$ & $6-7.9$ & $\geq 8$ & $<6$ & 6-7.9 & $\geq 8$ \\
\hline \multirow[t]{2}{*}{$\mathrm{CC}$} & $\mathrm{n}$ & 12 & 28 & 39 & 4 & 13 & 62 \\
\hline & $\%$ & 15.2 & 35.4 & 49.4 & 5.1 & 16.5 & 78.5 \\
\hline \multirow[t]{2}{*}{$\mathrm{CC}+\mathrm{E} 2$} & $\mathrm{n}$ & 10 & 26 & 46 & 1 & 14 & 67 \\
\hline & $\%$ & 12.2 & 31.7 & 56.1 & 1.2 & 17.1 & 81.7 \\
\hline$P$ & & .628 & .673 & .019 & .182 & .684 & .002 \\
\hline
\end{tabular}

Table 3. Uterine artery PI value on ovulation day and $7^{\text {th }}$ post-ovulation day

\begin{tabular}{|l|c|c|c|c|}
\hline \multirow{2}{*}{ Treatment Type } & \multicolumn{2}{|c|}{ Ovulation day } & \multicolumn{2}{c|}{${\mathbf{7}^{\text {th }} \text { post-ovulation day }}^{$\cline { 2 - 4 }$}$} \\
\cline { 2 - 5 } & Mean & Std. Deviation & Mean & Std. Deviation \\
\hline CC & 2.8071 & .78394 & 2.1875 & .87092 \\
\hline CC+E2 & 2.6115 & 1.32222 & 2.3333 & 1.05363 \\
\hline P & .616 & & .649 & \\
\hline
\end{tabular}

The ET of the patients who achieved or did not achieve pregnancy was $8.1 \pm 1.5$ and $7.9 \pm 1.8 \mathrm{~mm}$ on the OD and $10.0 \pm 2.1$ $\mathrm{mm}$ and $10.3 \pm 2.7 \mathrm{~mm}$ on the POD7 respectively. There was no significant difference on the OD or the POD7 between the ET of patients who achieved and did not achieve pregnancy.

The ET was evaluated on the OD and the POD7 in a total of 161 cycles and classified as $8 \mathrm{~mm}$ and over, 6 to $7.9 \mathrm{~mm}$, and less than $6 \mathrm{~mm}$. When divided into treatment groups, the ET values in the $\mathrm{CC}$ group and $\mathrm{CC}+\mathrm{E} 2$ group were presented OD in Table 2 and POD7 in Table 3. There was no difference between the CC and $\mathrm{CC}+\mathrm{E} 2$ groups for OD and POD7 when the ET was categorized as $8 \mathrm{~mm}$ or more, 6 to $7.9 \mathrm{~mm}$ and $6 \mathrm{~mm}$ or less.

The systemic E2, FSH, LH and progesterone levels of all patients in the $\mathrm{CC}$ group and $\mathrm{CC}+\mathrm{E} 2$ group were measured. There was no significant difference between the groups for the systemic hormone levels on D3, D9, OD and POD7. The UABF and SEBF pulsatility index (PI) was measured in all patients on the OD and POD7. There was no significant difference between the groups for arterial PI values on those days.

\section{Discussion}

We tried to determine whether it was possible to administer LE daily for fifteen days, starting from the $4^{\text {th }}$ day of the cycle in unexplained infertile patients using $\mathrm{CC}$ to prevent the possible detrimental effects of $\mathrm{CC}$ on the endometrium. The effect of vaginally administered estrogen on endometrial thickness in patients receiving clomiphene induction showed a significant increase on ovulation day and $7^{\text {th }}$ postovulation day.

The endometrium makes uterine attachment possible and can be evaluated directly with an endometrial biopsy but this method is invasive. Non-invasive methods have been investigated and various ultrasonographical parameters such as ET and uterine vascularization have been developed. Healthy blood perfusion of the uterus and ovaries may affect the success of assisted reproductive treatment (6-9). We therefore used the ET measurement to evaluate the endometrium and a Doppler investigation to determine whether the treatments we administered had led to a change in blood flow.

Estrogen may be used to prevent endometrial thinning but systemic estrogen (SE) administration might decrease the effect of CC by competitive inhibition. SE might also not reach a concentration high enough to thicken the endometrium. We believed these handicaps could be overcome by administering local (vaginal) E2. This study was mainly planned to determine whether it was possible to attain a relatively high local concentration with intravaginal E2 usage and therefore prevent the negative effects of $\mathrm{CC}$ on the endometrium, also preventing the systemic effects, and whether this could contribute to achieving implantation and pregnancy. In the end, as a result of the study, the ET increased significantly on OD and POD7 with CC and LE compared to CC alone. However, this difference in thickness did not lead to a difference in pregnancy rates. 
The fact that pregnancy rates were found to be higher in the untreated group in a study where one group received $\mathrm{CC}$ for infertility and the control group received no treatment was attributed to the anti-estrogenic activities of $\mathrm{CC}$ in estrogensensitive organs (10). The ET has been shown to remain thinner than natural cycles when $\mathrm{CC}$ was administered and this effect has been interpreted as the change created by $\mathrm{CC}$ in the estrogen receptor kinetics of the endometrium $(11,12)$. However, there is also a study stating that even if the endometrium stays thin, this does not lead to a significant change in pregnancy rates with ET values for the $6 \mathrm{~mm}$ or less, $6-8 \mathrm{~mm}$ and $8 \mathrm{~mm}$ or more groups on the ovulation day at $17.1 \%, 19.1 \%$ and $21.5 \%$ respectively (13). These unwanted physiological effects of $\mathrm{CC}$ continue to be scientific areas of interest. Some studies report that $\mathrm{CC}$ has a negative effect on uterine perfusion and the implantation rate. The ET as measured by USG has been shown not to increase in CC-induced cycles as much as in spontaneous or gonadotropin-induced cycles, and that even endometrial cell damage could develop $(14,15)$.

It is obvious that $\mathrm{CC}$ has multifactorial negative effects on reproductive end organs. We may postulate that this adverse effect on end organs may be minimized by LE without making any difference in the ovulation-inducing systemic effects. Other methods have been tried to eliminate these adverse effects that include low-dose CC use, starting $\mathrm{CC}$ intake on different days, starting at the early follicular phase, adding various agents, and various results have been reported (16-18).

The implantation and pregnancy rates have been found to be significantly higher compared to placebo in groups receiving E2 in studies on the effect of SE on infertile patients undergoing in vitro fertilization (19). Patients undergoing induction with CC were found to demonstrate a beneficial effect of SE on ET but effects that were not significant on the endometrial blood flow and the number of prevovulatory follicles (20). Fanchin et al. (21) have compared the effect of LE and SE in infertile patients receiving no other treatment and found that the LE group had better ET and SEBF. This is the first study aiming to minimize the adverse effects of $\mathrm{CC}$ on end organs where LE was added to $\mathrm{CC}$. A rest period of one month was used when changing from one treatment method to the other due to the cumulative effect of CC (22).

There may be various reasons for the lack of a difference in pregnancy rates in this study. The ET for all patients together was $6 \mathrm{~mm}$ or less in $13.7 \%$ on the ovulation day and $3.1 \%$ on the POD7. Kolibianakis et al. (13) have measured an endometrium thinner than $6 \mathrm{~mm}$ in $20.8 \%, 6-8 \mathrm{~mm}$ in $40.4 \%$, and $8 \mathrm{~mm}$ or more in $38.6 \%$ of their cases, but did not specify the POD7 measurements. The small percentage of patients with very thin endometrium compared to the general population in our study may be a reason for the lack of a difference in pregnancy rates between the treatment groups. Palomba et al. (23) have reported that the ET in the periovulatory and luteal phases decreased significantly, compared to the first cycle, on the $4^{\text {th }}$ cycle. An increasing number of cycles during treatment increases the degree the endometrium is affected and the thinning continues. Thickness is also not the only important factor for implantation and Hosie et al. (15) have shown by electron microscopic investigation of the endometrium that areas with marked cellular damage and lesions consisting of irregularly shaped cells are present on the endometrial surface and affect implantation.

Unfer et al. (19) have studied administering oral estrogen for 10 days in addition to $\mathrm{CC}$ and found no significant change in the FSH, LH and estrogen levels, while there was a significant increase in ET in the estrogen group. Another study on the association between ET and implantation measured the mean ET in those that did and did not achieve pregnancy as $10.2 \pm 2.6$ $\mathrm{mm}$ and $8.6 \pm 3.4 \mathrm{~mm}$ respectively with pregnancy rates $13.3 \%$ in those with values under $7.5 \mathrm{~mm}$ and no pregnancies in those with values under $5 \mathrm{~mm}$ (3).

Two studies on ET and continuing pregnancy compared infertile patients with ET measurements of less and more than $9 \mathrm{~mm}$ and found a significantly higher rate of continuing pregnancy in those with an ET more than $9 \mathrm{~mm}$ (24). Another study on the relationship between pregnancy and ET in patients who had undergone intrauterine insemination found a significant difference in ET between those who were pregnant $(10.1 \pm 3.0 \mathrm{~mm})$ and not pregnant $(7.7 \pm 3.5 \mathrm{~mm})$ (25). El-Toukhy et al. (26) have reported that both very thin $(<7 \mathrm{~mm})$ and very thick $(>14 \mathrm{~mm})$ endometrium have an adverse effect on implantation, with the highest pregnancy rates being seen in patients with an ET between 9 and $14 \mathrm{~mm}$.

Uterine vascularization and blood flow have been suggested as other possible noninvasive measures that determine uterine receptivity. Despite the anti-estrogenic effects of $\mathrm{CC}$ and its adverse effects, especially on ET and endometrial maturation, no significant difference has been found between natural cycles and those under $\mathrm{CC}$ regarding endometrial and subendometrial flow (11). We also did not find any significant difference between the treatment protocols. Unfer et al. (19) have similarly not observed a difference regarding Doppler flow parameters between the groups receiving and those not receiving E2.

\section{Conclusion}

We found that the ET results on OD and POD7 in patients receiving clomiphene induction showed a significant increase with LE addition. It may be beneficial in selected cases, but this increase was not reflected in the pregnancy rates in the current study. Larger series are required to demonstrate the effect of adding LE to CC stimulated cycles on pregnancy rates.

\section{Conflict of interest}

No conflict of interest was declared by the authors.

\section{References}

1. Haritha S. Rajagopalan G. Follicular growth, endometrial thickness, and serum estradiol levels in spontaneous and clomiphene citrateinduced cycles. Int J Gynecol Obstet 2003; 81: 287-92. [CrossRef]

2. Badawy A, Shokeir T, Allam AF, Abdelhady H. Pregnancy outcome after ovulation induction with aromatase inhibitors or clomiphene citrate in unexplained infertility. Acta Obstet Gynecol Scand 2009; 88: 187-91. [CrossRef] 
3. Abdalla HI, Brooks AA, Johnson MR, Kirkland A, Thomas A, Studd JW. Endometrial thickness: a predictor of implantation in ovum recipients? Hum Reprod 1994; 9: 363-5.

4. Dehbashi S, Parsanezhad ME, Alborzi S, Zarei A. Effect of clomiphene citrate on endometrium thickness and echogenic patterns. Int J Gynaecol Obstet 2003; 80: 49-53. [CrossRef]

5. Badawy A, Elnashar A, Totongy M. Clomiphene citrate or aromatase inhibitors for superovulation in women with unexplained infertility undergoing intrauterine insemination: a prospective randomized trial. Fertil Steril 2009; 92: 1355-9. [CrossRef]

6. Ng EH, Chan CC, Tang OS, Yeung WS, Ho PC. Endometrial and subendometrial vascularity is higher in pregnant patients with livebirth following ART than in those who suffer a miscarriage. Hum Reprod 2007; 22: 1134-41. [CrossRef]

7. Fouda UM, Sayed AM. Extended letrozole regimen versus clomiphene citrate for superovulation in patients with unexplained infertility undergoing intrauterine insemination: a randomized controlled trial. Reprod Biol Endocrinol 2011; 9: 84. [CrossRef]

8. Reindollar RH, Regan MM, Neumann PJ, Levine BS, Thornton KL, Alper MM, et al. A randomized clinical trial to evaluate optimal treatment for unexplained infertility: the fast track and standard treatment (FASTT) trial. Fertil Steril 2010; 94: 888-99. [CrossRef]

9. Chien LW, Au HK, Chen PL, Xiao J, Tzeng CR. Assessment of uterine receptivity by the endometrial-subendometrial blood flow distribution pattern in women undergoing in vitro fertilization-embryo transfer. Fertil Steril 2002; 78: 245-51. [CrossRef]

10. Fujii S, Fukui A, Fukushi Y, Kagiya A, Sato S, Saito Y. The effects of clomiphene citrate on normally ovulatory women. Fertil Steril 1997; 68: 997-9. [CrossRef]

11. Nakamura Y, Ono M, Yoshida Y, Sugino N, Ueda K, Kato H. Effects of clomiphene citrate on the endometrial thickness and echogenic pattern of the endometrium. Fertil Steril 1997; 67: 256-60. [CrossRef]

12. Birkenfeld A, Navot D, Levij IS, Laufer N, Beier-Hellwig K, Goecke C, et al. Advanced secretory changes in the proliferative human endometrial epithelium following clomiphene citrate treatment. Fertil Steril 1986; 45: 462-8.

13. Kolibianakis EM, Zikopoulos KA, Fatemi HM, Osmanagaoglu K, Evenpoel J, Van Steirteghem A, et al. Endometrial thickness cannot predict ongoing pregnancy achievement in cycles stimulated with clomiphene citrate for intrauterine insemination. Reprod Biomed Online 2004; 8: 115-8. [CrossRef]

14. Yagel S, Ben-Chetrit A, Anteby E, Zacut D, Hochner-Celnikier D, Ron $M$. The effect of ethinyl estradiol on endometrial thickness and uterine volume during ovulation induction by clomiphene citrate. Fertil Steril 1992; 57: 33-6.
15. Hosie MJ, Murphy CR. A scanning and light microscope study comparing the effects of clomiphene citrate, estradiol 17-beta and progesterone on the structure of uterine luminal epithelial cells. Eur J Morphol 1995; 33: 39-50.

16. Gerli S, Gholami H, Manna C, Di Frega AS, Vitiello C, Unfer V. Use of ethinyl estradiol to reverse the antiestrogenic effects of clomiphene citrate in patients undergoing intrauterine insemination: a comparative, randomized study. Fertil Steril 2000; 73: 85-9. [CrossRef]

17. Kamath MS, George K. Letrozole or clomiphene citrate as first line for anovulatory infertility: a debate. Reprod Biol Endocrinol 2011; 9: 86. [CrossRef]

18. Senturk LM, Erel CT. Thin endometrium in assisted reproductive technology. Curr Opin Obstet Gynecol 2008; 20: 221-8. [CrossRef]

19. Unfer V, Casini ML, Costabile L, Mignosa M, Gerli S, Di Renzo GC. High dose of phytoestrogens can reverse the antiestrogenic effects of clomiphene citrate on the endometrium in patients undergoing intrauterine insemination: a randomized trial. J Soc Gynecol Investig 2004; 11: 323-8. [CrossRef]

20. Unfer V, Costabile L, Gerli S, Papaleo E, Marelli G, Di Renzo GC. Low dose of ethinyl estradiol can reverse the antiestrogenic effects of clomiphene citrate on endometrium. Gynecol Obstet Invest 2001; 51: 120-3. [CrossRef]

21. Fanchin R, Righini C, Schönauer LM, Olivennes F, Cunha Filho JS, Frydman R. Vaginal versus oral E(2) administration: effects on endometrial thickness, uterine perfusion, and contractility. Fertil Steril 2001; 76: 994-8. [CrossRef]

22. Glazener CM, Coulson C, Lambert PA, Watt EM, Hinton RA, Kelly NG, et al. Clomiphene treatment for women with unexplained infertility: placebo-controlled study of hormonal responses and conception rates. Gynecol Endocrinol 1990; 4: 75-83. [CrossRef]

23. Palomba S, Russo T, Orio F Jr, Falbo A, Manguso F, Sammartino A, et al. Uterine effects of clomiphene citrate in women with polycystic ovary syndrome: a prospective controlled study. Hum Reprod 2006; 21: 2823-9. [CrossRef]

24. Giannaris D, Zourla A, Chrelias C, Loghis C, Kassanos D. Ultrasound assessment of endometrial thickness: correlation with ovarian stimulation and pregnancy rates in IVF cycles. Clin Exp Obstet Gynecol 2008; 35: 190-3.

25. Esmailzadeh S, Faramarzi M. Endometrial thickness and pregnancy outcome after intrauterine insemination. Fertil Steril 2007; 88: 432-7. [CrossRef]

26. El-Toukhy T, Coomarasamy A, Khairy M, Sunkara K, Seed P, Khalaf Y, et al. The relationship between endometrial thickness and outcome of medicated frozen embryo replacement cycles. Fertil Steril 2008; 89: 32-9. [CrossRef] 